\title{
CAUSES OF CONFLICT IN HABIBURRAHMAN EL-SHIRAZY'S NOVEL BUMI CINTA
}

\section{Hamzah Sya'bani Nasution, M. Manugeren, Purwarno Purwarno}

Faculty of Literature, Universitas Islam Sumatera Utara, Medan, Indonesia

e-mail: hamzah.nasution.007@gmail.com

\begin{abstract}
This study is concerned with the causes of conflicts in Habiburrahman El Shirazy's Novel Bumi Cinta which was published in 2019. The causes of conflicts derived from internal and external factors are the focus of the study. Through this study it is found that Ayyas can protect himself from the temptation that attacks his faith. He also surrenders himself to God so that he could be saved from all disturbances that come at any time to him. He is very angry with Linor who regards that his religion is a primitive one. The method used to analyze the causes of the conflict in this study is literary descriptive approach proposed in which it is shown that qualitative research methods are complex, changing and contested field site of multiple methodologies and research practices. The research results show that the main character faces internal as well as external conflicts in the forms of temptation and difference in perception.
\end{abstract}

Keywords: conflict, temptation, perception

\section{Introduction}

This study is concerned with causes of conflicts experienced by the main character of Habiburrahman El Shirazy's novel Bumi Cinta, focused on temptation and difference in perception. Besides novelist, scholar of Al-Azhar University, Cairo, Egypt, Habiburrahman El Shirazy is also known as a director, $d a{ }^{\prime} i$, and poet. His creations are in great devotee not only in Indonesia, but also in foreign countries like Malaysia, Singapore, Brunei, Hong Kong, Taiwan and Australia. His creations of fiction are considered to build spirit and foster the spirit of achievement. Among his creations that have been circulating in the market are Ayat-Ayat Cinta (have made the film version, 2004), Di Atas Sajadah Cinta (has a sinetron Trans TV, 2004), Ketika Cinta Berbuah Surga (When Love Fruitful of the Heaven) (2005), Pudarnya Pesona Cleopatra (Fading Enchanment of Cleopatra) (2005), Ketika Cinta Bertasbih (2007), Ketika Cinta Bertasbih 2 (December, 2007), Dalam Mihrab Cinta (2007), Bumi Cinta (Earth Love) (2010) and The Romance.

The conflicts that happen in the novel are internal conflict and external conflict. Each of the conflicts which is described in the novel has its own causes. The conflicts that are faced by the main character in the novel are not simple; in other words, they are very complicated and not easy to overcome. 
Internal conflict refers to a character's internal struggle. A character might struggle with an emotional problem such as fear of intimacy or abandonment, for example, internal conflict is important for characterization, since flaws and internal struggles make characters more lifelike and sympathetic. External conflict, on the other hand, refers to the conflicts between a character and external forces. This type of conflict can be between one character and another or a group (or between groups of characters). It can also be between a character and more abstract forces.

Both types of conflict, internal and external, are useful because they create tension. Because of conflict's uncertainty, we want to know how it resolves and keep turning pages to find out. They also create stakes. Conflict suggests worst-case outcomes and makes resolution urgent (the hero must overcome the antagonist/ environment or themselves). Besides, they create character development. Conflict allows for dramatic incidents that test characters and cause them to learn and adapt.

The main character of the novel, must face external conflicts as well as internal ones. He must face the reality that young beautiful women around him always tease him to do sexual intercourse. It is not easy for him to overcome the temptation though he is always able to stay away from them. There is a conflict in his mind. He must admit that he is still young and his willingness to be close to a young woman is there in his heart, but his closeness to the doctrine of his religion, Islam, makes him afraid do it. He also experiences conflict with a man who purposely challenges him to fight. It is because the man asks him impolitely to do a sexual intercourse with a young beautiful woman whom he has known well. He is really angry with him and makes him crazy.

\section{Literature Review}

In literature conflict is an inherent incompatibility between the objectives of two or more characters or forces. Conflict creates tension and interest in a story by adding doubt as to the outcome. By this, it is clear that through the medium of literature, people could learn more about life with all its dimensions and this is in line with the statements given by Purwarno (2019) that literature reflects the trends of the times in which it is produced and there is always a towering literary artist who becomes the mouthpiece of his age and gives expression to its hopes and aspirations, its fads and fetishes, its fears and doubts, its prosperity or poverty and its enterprise in his works.

\subsection{Conflict}

Conflict can be defined as a clash between individuals arising out of a difference in thought process, attitudes, understanding, interests, requirement and even sometimes perceptions. A conflict results in heated arguments, physical abuses and definitely loss of peace and harmony. A conflict can actually change relationships. Friends can become foes as a result of conflict.

Conflict is a state of discord caused by the actual or perceived opposition of needs, values and interest. A conflict can be internal (within oneself) or external (between two or more individuals). Conflict explains many aspects of social life such as social disagreement, conflict of interests and fight between individuals, groups or organizations.

According to Cooper (2003: 1), conflict is a collision of opposing interests. The collision may be relatively mild in nature as when two vehicles travelling in the same direction veer into each other's paths, striking only a glancing blow as each tries to recover, independently, and return appropriately to unoccupied space. Or the collision 
may be exceedingly violent as in the case of two speeding vehicles proceeding from opposite directions meeting each other unrestrained head-on.

Horton and Chester (1976: 3) state that conflict is a fundamental dynamic of human experience and interaction. It is the necessary struggle to balance concern for self with connections to others. It is because pain, suffering and stress are deeply associated with our perfection of conflict. As we know, the conflict happens from an event of a character. Thus, the character who has conflict is caused by any dissatisfaction of what to be hoped. In other words, there is a wish which is not fulfilled. For example, if protagonist is a poor girl, one conflict that might arise would be with nature, the poor itself.

Conflict in literature refers to the different drives of the characters or forces involved. Conflict may be internal or external- that is, it may occur within a character's mind or between a character and exterior forces, (or point(s) of view). Conflict is most visible between two or more characters, usually a protagonist and an antagonist/ enemy /villain, but can occur in many different forms. A character may as easily find himself or herself in conflict with a natural force, such as an animal or a weather event, like a hurricane. The literary purpose of conflict is to create tension in the story, making readers more interested by leaving them uncertain which of the characters or forces will prevail. (Robert, 1986: 103)

\subsection{Types of Conflict}

According to Stanton (1965: 16), there are two categories of conflict, namely external conflict and internal conflict. External conflict is a conflict occurring between a character and something outside himself /herself. It could be the environment and also human being or other characters. While internal conflict is a conflict that occurs in the heart or soul of characters. Further, these two kinds of conflicts can be further described as follows:

\subsubsection{Internal Conflicts}

One of the types of conflict is known as internal conflict. Internal conflict or a conflict which is there within a single man is a common thing to happen to every individual in their real life. The conflict within the single individual is reflected as well in a story. Thus, a story may also deal with a conflict within a single man. According to Kenney (1966: 19), the conflict happening within the single man is called 'internal conflict'. Coser (1913: 218), who sees conflict as instinctual for humans, says that internal conflict in the larger social system, as between different groups within the United States, releases hostilities, and creates norms. For dealing with the conflict, and developing lines of authority and judiciary systems, a society must always contend with the psychological need of individuals to engage in conflict. This need can build up over time and become explosive. Low level, frequent conflict tends to release hostilities. Those, hostilities keep conflict from building and becoming disintegrative for the system, the goals in this internal conflict is usually called "psychological conflict". The examples of the internal conflict are: man versus himself and man versus man. Internal conflict is often referred to as man versus himself since the struggle is inside one's head.

\subsubsection{External Conflicts}

It is added by Kenney that the conflicts which fiction concerns itself are many kinds of conflict. In addition to internal conflict, conflicts between men, conflicts 
between society and men, between men and nature are also reflected in a work of literature, for instance in one type of literature, a novel. This kind of conflict is called external conflict. The conflict is described more profoundly in terms of external conflict. The tragic vision presented is man in conflict with other forces greater than himself. The other forces operating in these plays are described as fate, destiny, chance and necessity. External conflict is a struggle between a character and an outside force is an external conflict. For examples of external conflict is characters may face several types of outside forces. Types of external conflict are such as: man versus man, man versus nature, man versus society, and man versus technology.

Coser (1913: 219) states that external conflict is the different groups involved in conflict also experience functional results especially, when the conflict is more violent. As a group experiences external conflict, the boundaries surrounding the group become stronger, the members of the group experience greater solidarity, power is exercised more efficiently, and the group tends to form coalitions with other groups the more violent the conflict is, the more intensified are these effects. In order for any group to exist, it must include some people and exclude others. This inclusion or exclusion process involves producing, and regulating different behaviors, ways of feeling and thinking, cultural symbols, and so forth.

\subsection{Causes of the Conflict}

\subsubsection{Temptation}

Temptation is an internal conflict of desire whereby an agent desires some state of affairs, which state of affairs the agent takes to be bad, and simultaneously has some internal state (e.g. desire, reason, intention, etc.), which is seen as good, that conflicts with either the bad desire or the obtaining of the bad state of affairs desired. (Snider, 2017)

\subsubsection{Difference in Perception}

Differences in perceptions, values and attitudes of individuals or groups over the same problem lead to interpersonal or intergroup conflicts. For example, one group of individuals may want that all employees use HP computers to maintain standardization while another group may promote different brands of computers to maintain individuality. Differences in views can lead people to undergo conflicts (Snider, 2017).

\section{Research Method}

In completing this writing, the writer applies the method which is called literary descriptive approach. Punch (1988: 1993) says that qualitative research methods are complex, changing and contested field site of multiple methodologies and research practices.

In addition, the writer also analyzes the characteristics of available conflict in it. It is done in order to clarify each several kinds of conflict found in the novel. Thus, the clarification of conflict can be analyzed properly in terms of literary analysis. The data are analyzed qualitatively. The data are connected with some events in the novel. The data constitute a tool of information which is taken from data source. Therefore, the data in this thesis are dialogues of the main character and narrations which derive from the novel. 


\section{Results and Discussion}

\subsection{Temptation}

At the first time he arrives in Moscow, Ayyas is reminded by his friend. Devid, that he should be careful about the temptation of girls. Devid tells him that most of the girls of the city are sweet and beautiful. He purposely reminds him about it because he knows well that Ayyas always feels reluctant to be close to many girls. He adds that the temptation of the girls from Moscow is more powerful than the temptation of the girls from many towns in Java.

Devid is the only man that Ayyas knows well in Moscow. Ayyas has known him since they were the students of the same Junior High School in Indonesia. When they were still the students of the same school, he saw that Devid was a boy who always used his words politely. He always did something based on the doctrine of his religion, Islam. He did not want to do anything which was forbidden by the doctrine of his religion. However, he changes now. He is no longer as he was in the past time. He has become a man who does not care about the doctrine of his religion anymore. He does not care about how he must behave in his association with girls.

Ayyas cannot really hope him anymore to be a friend who can save him from the temptation of beautiful girls of the city. He even sees him to be brave enough to offer him a girl to be dated. He realizes that Devid does not reluctant to do such a thing to him who hates to do it. He really feels that this is a form of faith temptation that disturbs his mind.

Devid no longer saw the rules of religion in his association with the opposite sex. He felt Devid was hard to be relied upon as a friend who would be able to keep the faith and cleanliness of his soul. He only hoped that God would give mercy to him so that he would survive while leaving in this capitalist, communist country. "You know Yas, this old driver offered us Russian girls?" Devid told Ayyas. "Yes I know." "You want?" "Crazy you Dev! That's adultery! Unclean!" "He he he ! It's good that you still hold on to your belief. I want to know how strong your faith is here. For me, just sorry, I don't want to be bound by any religious rules. He he he." Devid's mockery while giggling (El Shirazy, 2010: 25)

In the above quotation, it can be seen that Ayyas's faith is being examined. His faith is being tempted through Devid's words. Devid told him that the driver of the car they were riding in offered Russian girls to them to be dated. He gets surprised to hear what Devid has told him. Then he is angry with him even though later Devid explains to him that he only wants to know how strong his faith is. He is even very upset to know that now Devid does not want to be bound by any religious rules.

When, at the first time, they arrive at the apartment where he will stay, he sees a beautiful young girl comes closer to them. The girl greets Devid and smiles at them. Then Devid introduces him to the girl who later shakes his hand. She smiles at him when she shakes his hand. Then she leaves them. Knowing what is happening, Devid tells him to use the opportunity to be closer to her later. However, Ayyas does not like to hear what Devid has just told him.

"Sorry, I have to go to Tverskaya, there is an event. At eight in the evening I go home. I'll go first." Yelena answered and immediately rushed out the building. Devid followed Yelena's steps until they were 
out of sight. "Isn't it beautiful, Yas? There's Finland's blood in her. You're lucky. You're going to live in the same apartment with her. Use your best opportunities." Devid muttered, smiling teasingly at Ayyas. "What Dev? You don't mess with me. I'm still in my right mind Dev! I can't possibly live freely like you!" Ayyas' face turned red. He felt that Devid was deliberately playing with him by renting out an apartment with a Caucasian girl who was said to be of Finnish blood (El Shirazy, 2010: 30-31).

Through the above quotation, it can be seen clearly that the faith of Ayyas is again tempted by the words of Devid. His mind is disturbed by Devid's words that influence his desire as a young man. There is an internal conflict in his mind. He has always tried his best to avoid being close to a young woman because of her beauty or body shape. He becomes angry with him after being informed that he will stay together with the girl in the same apartment. He thinks that Devid has done it purposely to tempt his faith.However, later Devid asks his apology and asks him to come into the room where he will stay for some months.

After Devid leaves him to buy some things out side, he then observes a prayer. Later he feels that the test of faith in Moscow will be very hard on him. He has two neighbors and they are young Russian women. He feels that he will be very weak; his faith will surely collapse in Moscow if it is not helped and guarded by Allah, the Almighty God. He knows how strong his faith is. The war against the enemy on the battlefield might remain firm until the body falls covered in blood. His faith will not shrink and collapse by the sharp flash of a sword. He was not afraid at all. But before the slander of women's beauty as clear as Moscow girls, like Yelena, he felt his faith could slowly melt like salt drenched in water.

He feels that he does not have any fortress and weapons to guard his faith, except praying to God to ask that the faith in his heart not be uprooted in any condition. He believes very well that only God can maintain his faith. Only Allah can save him from all slander and satanic deception. His anxiety to the temptation of his faith can be described through the following quotation:

Ayyas straightened in his prayer. Fear of slander of woman spreads throughout the nerves and blood flow. His heart and mind are united in persuasion to God. In prostration he prayed, "O God, bless Your servant by leaving immorality forever, as long as Your weak servant is given a life in this world. O God who turns the heart, strengthen the heart of Your servant firmly holding Your religion, strengthen the heart of Your servant to obey You and to abandon all Your prohibitions. Amen.” (El Shirazy, 2010: 40)

The above quotation describes that there is an anxiety of faith temptation that he has just experienced. There is an internal conflict in his mind, that is, he is afraid that beautiful young women who live around him will be able to temp his faith. He is afraid that young beautiful women who live in a free sex lifestyle will plunge him into the valley of immorality. In order that he can be saved from the immoral deeds, he prays to God to always protect him from all the temptations that will make him fall into the valley of immorality. 
Another faith temptation that is experienced by Ayyas is at the moment he has just returned home from his visit to meet a professor at a university where he will do his research for some months and other places in Moscow including the Embassy of Indonesia.

After pressing the doorbell, Yelena opens the door and soon she sits on a chair in a living room. Then Ayyas comes in and sees her sitting on the chair. He gets very surprised to look at her because of her performance. She is wearing a cloth so thin that she looks so sexy and seductive. What he is looking at in front of him can really make him tempted. Therefore, he does not want to see her linger that can cause him to be seduced. This temptation of faith that he is experiencing now can be described through the quotation below.

The rather thin young man took off his shoes and entered the living room. He was surprised very much when she saw Yelena sitting in the living room with clothes that did not even cover genitalia. $\mathrm{He}$ immediately lowered his gaze. He felt that the room was packed with demons clapping to greet him."Hey, just got home, successful business?" Yelena asked with a smile. Without looking at Yelena and still walking towards his room, Ayyas answered, "Yes, successful. Spakoinoi Nochi, Yelena!" Yelena got up and said, "Hey wait, sit here for a while. Warm yourself up with this Vodka. Accompany me to chat for a while." "Sorry Yelena, I'm so tired, I have to rest." "Just sit for fifteen minutes." "Sorry Yelena, I can't. You should just rest." said Ayyas while still holding back not to look at Yelena. He actually wanted to slightly direct his face to Yelena's face to respect the other person. But, he did not dare, for fear of rocking his faith. (El Shirazy, 2010: 90-91)

From the above quotation, it can be seen that Ayyas' faith is being tempted by Yelena. She purposely does it by wearing sexy clothes in front of him. In other words, some parts of her body which actually may not be shown to anybody else, especially male persons, can be seen by Ayyas. However, he quickly averts his eyes from Yelena's body. Even though she asks him to come closer to her and sit beside her, he does not want to do it. He goes on to walk to come into his room which is actually close to his room.

In order to respect Yelena, he tells her that he is very tired and wants to take a rest as soon as possible. He walks towards his room while bowing his head and telling her to take a rest too. On the other side, she continues to tease him to sit next to her and accompany her for several minutes. She even offers him to drink Vodka to warm his body. He does not want to come closer to her and drink such an intoxicating drink. He is afraid that later his faith will be tempted. He keeps trying not to see her body's parts which are indeed able to tempt his sahwat disires to do things that are forbidden by religion.

\subsection{Difference in Perception}

A few hours after he stays in his apartment, Ayyas has a guest. He gets surprised because his guest is a beautiful young woman. His heart rustles. The beautiful face of the young woman really almost bewitches him. He is nervous in doing face to face with the young woman, even though it is accidental. Then, he 
takes a breath slowly to get rid of his nervousness. Slowly, he is able to begin to control himself and his mind which has shaken.

The woman who just introduces herself is named Yelena. She invites him to eat together, and this offer cannot be refused by him even though he feels nervous about eating together with a beautiful woman like Yelena. He prays to God to protect himself and his faith. Yelena takes a seat right opposite Ayyas and he looks down a lot and tries hard to keep a look.

When they are taking their foods, Yelena cynically says that he is a devout Islamic person. He responds that he is only trying to be devout. He guesses that she is a Christian Orthodox, but she denies it. She tells him that she has ever been the follower of many religions, and the last is Islam. However, she makes him shocked because she tells him that she does not believe anymore in all religions. She does not even believe in God. This is certainly contrary to his belief that God exists. He is really confused why such a beautiful young woman does not believe in God and religions. This difference in perception can be described through the quotation below.

"Are you a devout Muslim?" Yelena said as she chewed the food she was carrying. "Trying to obey. For you, sorry, Orthodox huh?" Ayyas was sure his guess was right. Because the majority of Russians embrace Orthodox Christianity after the collapse of the communist regime of the Soviet Union. "No, I used to have embraced a religion. I have ever been Buddhist, eve Confucian, ever Orthodox, and ever Muslim?" "Have you ever embraced Islam?" "Yes I have, that's because my ex-husband is a Muslim." "Now?" "I don't brace any religion. I don't believe in religion anymore. Als God."

(El Shirazy, 2010: 50-51)

After hearing it she does not believe in any religions anymore, as described in the above quotation, Ayyas is very surprised. He does not like her statement very much telling that she does not believe in any religions, and even in God. He feels just struck by lightning that blaring from the seventh heaven sky. Indeed, for matters of religion and matters of divinity, he is quite sensitive. For people who do not recognize the existence of God on this earth, his heart boils easily. In other words, he gets very angry with them. He really disagrees with Yelena's statement that there is no God, even more boiling towards people who offend or insult his religion, Islam. Their different perception over religion and God can also be seen in the quotation below.

"Innalillah!" excited Ayyas. "Don't be surprised. There are so many people who are not religious. In my opinion, for our lives to be easy and to have many conveniences, we do not need religion, either God. The existence of religion and God is only causing trouble!" "That's not true. Religion exists to solve the problems that afflict mankind.“"'That's only a theory. In reality it is not like that. Almost all of these human problems are solved due to the greatness of science and technology that is dominated by humans. Not because of God. It is because God is also the creation of human beings. If we agree that God does not exist, then there must be none" explained Yelena seriously. "You may say whatever you want. God still exists. Even though all the inhabitants of this earth say and believe God does not 
exist, God still exist. God has existed before the universe including the whole world and humans. The existence of God means postular truth." (El Shirazy, 2010: 51-52)

In the above quotation, it is found that there is different perception between Ayyas and Yelena about religion and God. According to Ayyas, God must exist and every human being must have their own religion. On the contrary, according to Yelena, God does not exist and every human being does not need to have any religion. In Yelena's opinion, the existence of God and religion only causes trouble, while according to Ayyas, the existence of the Almigthy God and religion must be absolute and religion will solve all the problems that everyone has. However, Yelena believes that human beings will be able to solve their problems of life because they have knowledge to do it.

\section{Conclusion}

Conflict constitutes a social process between two persons or more in which one of them tries to defeat another one by destroying him/her or making them helpless. Then conflict also arises when two or more individuals or groups think differently, caused by different perceptions that different individuals hold about the same object or goal. Conflict is always there in the life of human being whether it is internal conflict or external conflict.

The main character of Habiburrahman El Shirazy's novel Bumi Cinta experience conflicts caused by temptation and difference in perception, both from internal and external factors. And for both factors, the main character has to struggle hard to overcome all the problems; and that is the reason that from the very beginning it is seen and stated that facing conflicts, either internal or external, is a very complicated matter. And owing to a firm principle, the main character could overcome all the conflicts well.

\section{References}

Cooper, H. H. A. Tony. (2003). What Is Conflict? How Are Conflicts Resolved? Journal of Police Crisis Negotiation, Vol. 3 (1) 2003. Dallas: The Haworth Press, Inc.

Coser, Lewis Alfred. (1913). Toward a Sociology of Social Conflict (PhD). Columbia University. p. vi. OCLC 310906539. Retrieved August 30, 2019.

El Shirazy, Habiburrahman. (2010). Bumi Cinta. Jakarta : Author Publising.

Horton, Paul and Chester, L.Hurt. (1976). General Conflict. New York : Random House. Inc

Kenney, William. (1966). How to Analyze Fiction. USA: Simon and Schuster.

Punch, K. F. (1988). From Research Questions to Data. Introduction to Social Research. London: Sage.

Purwarno, et.al. (2019). Medieval Religious Officials in Geoffrey Chaucer's Prologue to Canterbury Tales" in The Second Annual International Conference on Language and Literature, $\mathrm{KnE}$ Social Sciences. Retrieved from DOI 10.18502/kss.v3i19.4887

Roberts, Edgar V.; Henry E. Jacobs. (1986). Literature: An Introduction to Reading and Writing. Prentice-Hall.p. 103. ISBN 013537572X.

Snider, Kevin. (2017). The Nature of Temptation. Lee University.

Stanton, Robert. (1965). An Introduction to Fiction. Yogyakarta: Pustaka Pelajar. 